\title{
Development of a Low-Melting-Point Filler Metal for Brazing Aluminum Alloys
}

\author{
T.H. CHUANG, M.S. YEH, L.C. TSAO, T.C. TSAI, and C.S. WU
}

The study is concerned with developing low-melting-point filler metals for brazing aluminum alloys. For this purpose, thermal analyses of a series of $\mathrm{Al}-\mathrm{Si}-\mathrm{Cu}-\mathrm{Sn}$ filler metals have been conducted and corresponding microstructures observed. The results showed that the liquidus temperature of Al-Si$\mathrm{Cu}$ filler metals dropped from $593{ }^{\circ} \mathrm{C}$ to $534{ }^{\circ} \mathrm{C}$, when the amount of copper was increased from 0 to 30 pct. As the copper content reached further to 40 pct, the liquidus temperature would rise to 572 ${ }^{\circ} \mathrm{C}$. By adding 2 pct tin into the $\mathrm{Al}-\mathrm{Si}-20 \mathrm{Cu}$ alloys, the liquidus and solidus temperature would fall from $543{ }^{\circ} \mathrm{C}$ to $526{ }^{\circ} \mathrm{C}$ and from $524{ }^{\circ} \mathrm{C}$ to $504{ }^{\circ} \mathrm{C}$, respectively. The main microstructures of Al-Si$\mathrm{Cu}$ alloys consist of the $\alpha$-Al solid solution, silicon particles, the $\mathrm{CuAl}_{2}(\theta)$ intermetallic, and the eutectic structures of $\mathrm{Al}-\mathrm{Si}, \mathrm{Al}-\mathrm{Cu}$, and $\mathrm{Al}-\mathrm{Si}-\mathrm{Cu}$. For further improvement of the brazability of this filler metal, magnesium was added as a wetting agent, which would remove the residual oxygen and moisture from the brazed aluminum surface and reduce the oxide film. Based on results gleaned from the thermal analyses, a new filler metal with the composition $\mathrm{Al}-7 \mathrm{Si}-20 \mathrm{Cu}-2 \mathrm{Sn}-1 \mathrm{Mg}$ is proposed, which possesses a melting temperature range of $501{ }^{\circ} \mathrm{C}$ to $522{ }^{\circ} \mathrm{C}$ and a microstructure that includes an $\mathrm{Al}-\mathrm{Si}$ solid solution, silicon particles, a tin-rich phase, and $\mathrm{CuAl}_{2}, \mathrm{CuMgAl}_{2}$, and $\mathrm{Mg}_{2} \mathrm{Si}$ intermetallic compounds. When this filler metal was used to braze the 6061-T6 aluminum alloy, an optimized bonding strength of $196 \pm 19 \mathrm{MPa}$ was achieved.

\section{INTRODUCTION}

OWING to their high specific strength, low cost, and superior corrosion resistance, aluminum alloys have been widely used in aerospace, automobile, and construction industries. Also, by virtue of good thermal conductivity, they are often employed in heat exchanger manufacturing. In industrial application, the bonding problem with these aluminum alloys has always been a serious consideration. Among a variety of techniques, brazing has been adopted as a reliable method for the bonding of aluminum components, ${ }^{[1]}$ wherein a eutectic Al-12Si (wt pct) alloy is recognized as the most popular filler metal. ${ }^{[2,3]}$ Although a sound joint can be obtained with this traditional filler metal, its brazing temperature is high relative to the melting point of pure aluminum due to the high eutectic point of the Al-12Si alloy at about $577{ }^{\circ} \mathrm{C}$, which can bring about degradation of mechanical properties or even localized melting in some engineering aluminum alloys when brazed. Therefore, the development of a low-melting-point filler metal with a satisfactory bonding strength is an important task for the aluminum industry. For this purpose, a series of efforts have been made in the past few years. Humpston et al. ${ }^{[4]}$ and Jacobson et al. ${ }^{[5]}$ had developed an $\mathrm{Al}-20 \mathrm{Cu}-2 \mathrm{Ni}-5 \mathrm{Si}$ filler metal with a melting temperature range between $518{ }^{\circ} \mathrm{C}$ and $538{ }^{\circ} \mathrm{C}$. For the brazing of a $3003 \mathrm{Al}$ alloy with this filler metal, a shear strength over $75 \mathrm{MPa}$ was obtained. Suzuki et al. ${ }^{[6]}$ reported on a eutectic $\mathrm{Al}-4.2 \mathrm{Si}-40 \mathrm{Zn}$ filler metal with a melting point

T.H. CHUANG, Professor, L.C. TSAO, Doctoral Candidate, and T.C. TSAI, Postdoctor, are with the Institute of Materials Science and Engineering, National Taiwan University, Taipei 106, Taiwan, Republic of China. M.S. YEH, Associate Professor, is with the Department of Mechanical Engineering, Chung-Hua University, Hsin-Chu 300, Taiwan, Republic of China. C.S. WU, Engineer, is with the Metal Industries Research and Development Center, Kaohsiung 811, Taiwan, Republic of China.

Manuscript submitted November 18, 1999. of $535{ }^{\circ} \mathrm{C}$. The disadvantage of that filler metal lies in the fact that the vapor pressure of zinc is very high and thus unsuitable for the vacuum brazing process. Kayamoto et $a l^{[7]}$ found a low-melting-point Al-Ge-Si-Mg filler metal. When that filler metal was applied to braze a 6061 aluminum alloy at $575{ }^{\circ} \mathrm{C}$ for 60 minutes, the brazed joints provided sufficient joint strength equal to that of the base alloy. However, germanium is approximately 400 times the price of aluminum, making the alloy excessively expensive for most applications.

In this present study, an $\mathrm{Al}-7 \mathrm{Si}-20 \mathrm{Cu}-2 \mathrm{Sn}-1 \mathrm{Mg}$ filler metal with a low melting temperature range of $501{ }^{\circ} \mathrm{C}$ to $522{ }^{\circ} \mathrm{C}$ has been developed. When applied to braze the 6061-T6 aluminum alloy, this filler metal displayed excellent wettability and a high bonding strength of $196 \pm 19 \mathrm{MPa}$.

\section{EXPERIMENTAL}

In order to develop a low-melting-point and high strength filler metal for the brazing of aluminum alloys, a series of Al-Si-Cu alloys with the compositions shown in Table I were prepared by melting in alumina crucibles equipped with an air furnace. The Al-Si alloys were molten first at $700{ }^{\circ} \mathrm{C}$, and then the temperature was raised to $1000{ }^{\circ} \mathrm{C}$ when various amounts of copper $(99.9 \mathrm{wt}$ pct, 2 -mm-diameter slug) were added into the molten aluminum alloy. Then, the mixture was stirred for 30 minutes for homogenization. Some Al-Si-Cu master alloys were further added with tin and magnesium elements. They were then cast in a stainless steel mold.

The thermal analyses for various filler metals $(20 \mathrm{mg})$ were conducted with a DU PONT* model 2000 differential

*DU PONT is a trademark of E.I. Du Pont de Nemours \& Co., Inc., Wilmington, DE.

thermal analyzer (DTA). The specimens were heated from 
Table I. Chemical Compositions and Thermal Properties of $\mathrm{Al}-\mathrm{Si}-(\mathrm{Cu}, \mathrm{Sn}, \mathrm{Mg})$ Filler Metals in This Study

\begin{tabular}{|c|c|c|c|c|c|c|c|}
\hline \multirow[b]{2}{*}{ Sample } & \multicolumn{4}{|c|}{$\begin{array}{c}\text { Chemical Compositions } \\
\text { (Wt Pct) }\end{array}$} & \multirow{2}{*}{$\begin{array}{l}T_{S}^{*} \\
\left({ }^{\circ} \mathrm{C}\right)\end{array}$} & \multirow{2}{*}{$\begin{array}{l}T_{L}{ }^{*} \\
\left({ }^{\circ} \mathrm{C}\right)\end{array}$} & \multirow{2}{*}{$\begin{array}{l}\Delta T^{*} \\
\left({ }^{\circ} \mathrm{C}\right)\end{array}$} \\
\hline & $\mathrm{Si}$ & $\mathrm{Cu}$ & $\mathrm{Sn}$ & $\mathrm{Al}$ & & & \\
\hline 1 & 12.0 & 0 & 0 & bal & 579 & 593 & 14 \\
\hline 2 & 11.4 & 5 & 0 & bal & 523 & 579 & 56 \\
\hline 3 & 10.8 & 10 & 0 & bal & 522 & 565 & 43 \\
\hline 4 & 10.2 & 15 & 0 & bal & 523 & 548 & 25 \\
\hline 5 & 7.0 & 15 & 3 & bal & 504 & 545 & 41 \\
\hline 6 & 9.6 & 20 & 0 & bal & 524 & 543 & 19 \\
\hline 7 & 9.0 & 25 & 0 & bal & 523 & 537 & 14 \\
\hline 8 & 8.4 & 30 & 0 & bal & 523 & 534 & 11 \\
\hline 9 & 7.8 & 35 & 0 & bal & 522 & 558 & 36 \\
\hline 10 & 7.2 & 40 & 0 & bal & 523 & 572 & 49 \\
\hline 11 & 7.0 & 20 & 2 & bal & 504 & 526 & 22 \\
\hline 12 & 7.0 & 20 & $2 \mathrm{Sn}-1 \mathrm{Mg}$ & bal & 501 & 522 & 21 \\
\hline 13 & 7.0 & 20 & 3 & bal & 504 & 526 & 22 \\
\hline 14 & 9.0 & 20 & 5 & bal & 504 & 523 & 19 \\
\hline 15 & 8.4 & 20 & 10 & bal & 504 & 520 & 16 \\
\hline
\end{tabular}

$* T_{S}$ indicates the solidus temperatures of the filler metals. $T_{L}$ indicates the liquidus temperatures of the filler metals. $\Delta T=$ $T_{L}-T_{S}$.

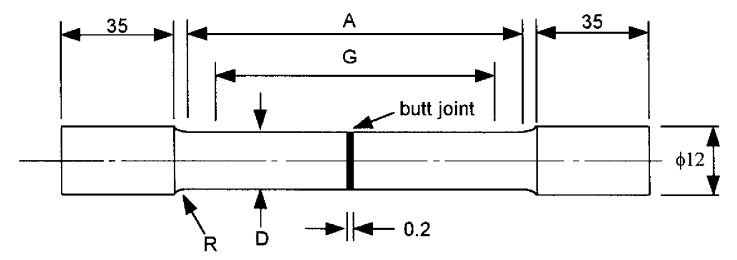

\begin{tabular}{|c|c|}
\hline G: Gage length & $50.00 \pm 0.06 \mathrm{~mm}$ \\
\hline D: Diameter & $10.00 \pm 0.02 \mathrm{~mm}$ \\
\hline R: Radius of fillet, min & $4 \mathrm{~mm}$ \\
\hline A: Length of reduced section, $\min$ & $60 \mathrm{~mm}$ \\
\hline
\end{tabular}

Fig. 1-Geometry and dimensions of the butt joint specimen for tensile testing.

room temperature to $600{ }^{\circ} \mathrm{C}$ at a heating rate of $10{ }^{\circ} \mathrm{C} / \mathrm{min}$ under argon atmosphere. The microstructure was observed by means of optical microscopy and scanning electron microscopy after metallographic preparation and etching in 10 vol pct $\mathrm{H}_{3} \mathrm{PO}_{4}$ at $50{ }^{\circ} \mathrm{C}$ for 60 seconds. The phases as observed in the microstructure were identified with an $\mathrm{X}$ ray diffractometer (XRD), an energy dispersive X-ray spectroscope, and an electron probe microanalyzer (EPMA). Finally, 6061-T6 aluminum alloy rods with a diameter of 12 $\mathrm{mm}$ were brazed in a vacuum furnace with the developed filler metal. For comparison, the conventional Al-12Si filler metal was also used. The brazing process was carried through in a vacuum of $5 \times 10^{-5}$ torr for various specimens, respectively, at $550{ }^{\circ} \mathrm{C}, 575{ }^{\circ} \mathrm{C}$, and $600{ }^{\circ} \mathrm{C}$ for 30 or 60 minutes. Some specimens after brazing were treated in a T6 temper condition: solution treated at $520{ }^{\circ} \mathrm{C}$ for 1.5 hours, water quenched, and then aged at $175^{\circ} \mathrm{C}$ for 8 hours. The bonding strength at the butt joint was measured via tensile testing at a constant crosshead speed of $10^{-4} \mathrm{~ms}^{-1}$ at room temperature. The specimens for tensile testing were prepared from brazed samples, and their geometry and dimensions are given in Figure 1. In order to ascertain reproducibility, at least three specimens were tested for each brazing condition.

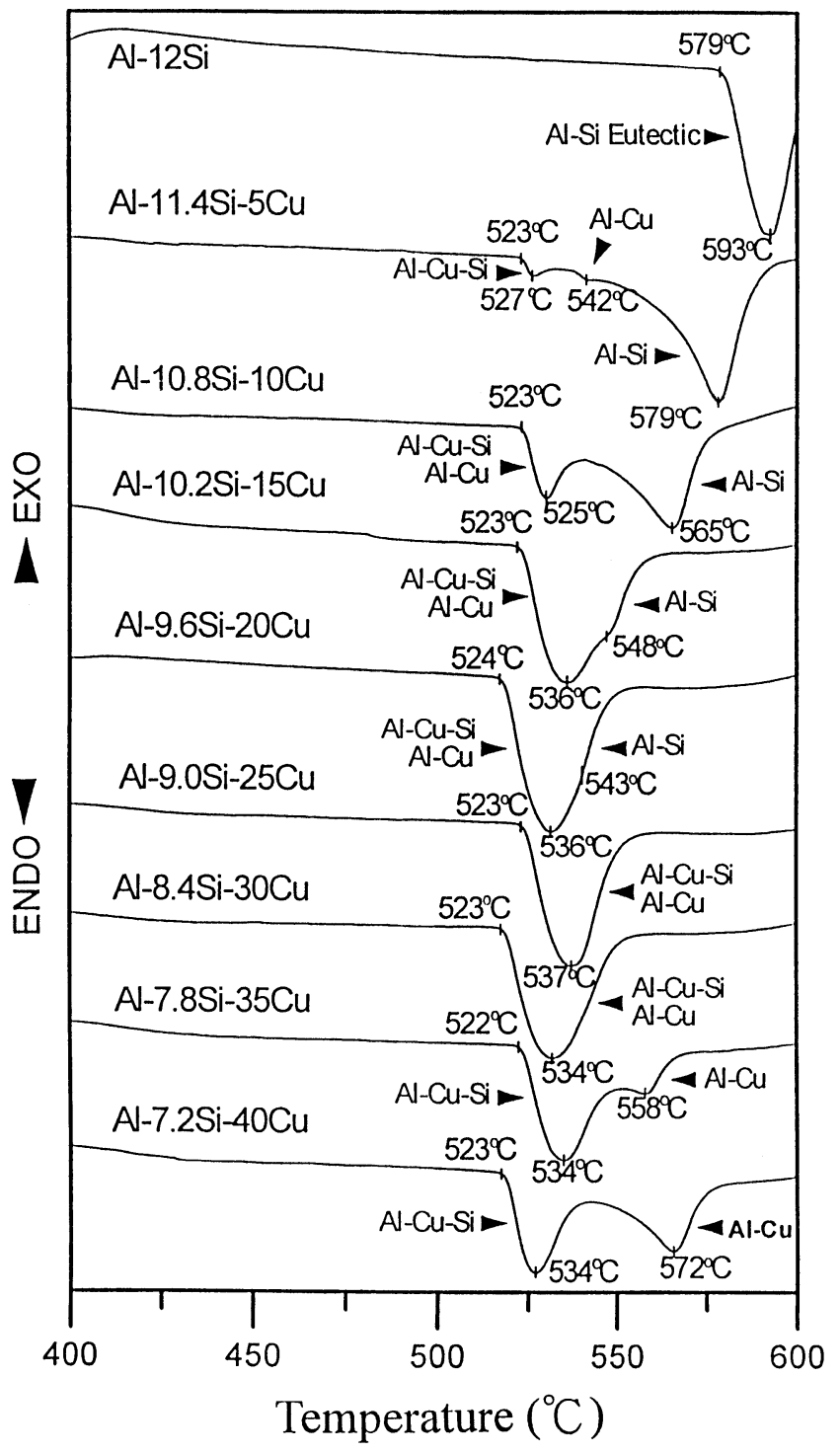

Fig. 2-DTA curves of the Al-12Si alloy and Al-Si-Cu filler metals.

\section{RESULTS AND DISCUSSION}

Figure 2 shows the DTA curves of various filler metals used in this study. The melting temperatures (solidus and liquidus) were taken from the DTA curves listed in Table I. Since the heating process in the DTA analysis was in a nonequilibrium condition, the eutectic $\mathrm{Al}-12 \mathrm{Si}$ alloy showed a melting temperature range from $579{ }^{\circ} \mathrm{C}$ to $593{ }^{\circ} \mathrm{C}$, rather than the equilibrium eutectic point at $577{ }^{\circ} \mathrm{C}$. Figure 3 showed two distinct structures as observed in the Al-12Si alloy: a lamellar Al-Si eutectic structure and an $\alpha$-Al dendrite solid solution (shown as large white areas).

Adding 5 pct copper to the Al-12Si alloy would cause the solidus temperature to drop drastically from $579{ }^{\circ} \mathrm{C}$ to $523{ }^{\circ} \mathrm{C}$. As the copper content increased further to $40 \mathrm{pct}$, the solidus temperature still remained constant. However, the liquidus temperatures of these $\mathrm{Al}-\mathrm{Si}-\mathrm{Cu}$ ternary alloys decreased from $593{ }^{\circ} \mathrm{C}$ to $534{ }^{\circ} \mathrm{C}$ when copper was added up to $30 \mathrm{pct}$, and then it would go up with the further increasing of the copper content. The result was consistent with the Al-Si-Cu ternary phase diagram, ${ }^{[8]}$ which showed 


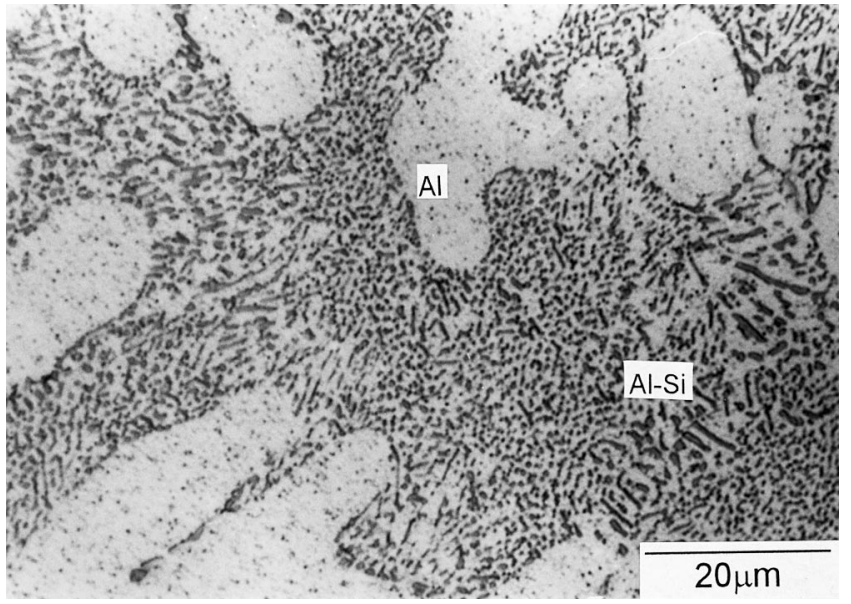

Fig. 3-Microstucture of the Al-12Si eutectic alloy, in casting condition.

a ternary eutectic point at $525{ }^{\circ} \mathrm{C}$ with the $\mathrm{Al}-5.2 \mathrm{Si}$ 26.7 Cu composition.

Two endothermic peaks were found in the DTA curve of the Al-11.4Si-5Cu ternary alloy (shown in Figure 2), which corresponded to the $\mathrm{Al}-\mathrm{Cu}-\mathrm{Si}$ ternary eutectic point and $\mathrm{Al}-$ $\mathrm{Cu}$ binary eutectic point at $527^{\circ} \mathrm{C}$ and $542{ }^{\circ} \mathrm{C}$, respectively. Increasing the copper content up to 25 pct caused the endothermic peaks to approach each other. For the $\mathrm{Al}-9 \mathrm{Si}-25 \mathrm{Cu}$ alloy, which was near the $\mathrm{Al}-5.2 \mathrm{Si}-26.7 \mathrm{Cu}$ ternary eutectic composition, only one endothermic reaction was found in its DTA curve. When the copper addition went higher than 35 pct, two separated endothermic peaks in the DTA curve appeared again. For the development of a low-melting-point $\mathrm{Al}-\mathrm{Si}-\mathrm{Cu}$ alloy, the copper content was therefore suggested to range between 20 to 30 pct.

The microstructure of the Al-11.4Si-5Cu ternary alloy was composed of an $\mathrm{Al}-\mathrm{Si}$ eutectic phase, a dendrite $\alpha$-Al solid solution, and the $\mathrm{CuAl}_{2}(\theta)$ intermetallic compound (Figure 4(a)). When the copper content in Al-Si-Cu alloys was higher than $10 \mathrm{pct}$, some silicon particles (average size about $25 \mu \mathrm{m}$ ) with an $\mathrm{Al}-\mathrm{Si}$ eutectic phase around them could be detected (Figure 4(b)). The scale of the Al-Si eutectic phase was reduced along with further increasing of the copper content. For the microstructure of the $\mathrm{Al}-9 \mathrm{Si}-25 \mathrm{Cu}$ alloy displayed in Figure 4(c), the Al-Si eutectic phase and the dendrite $\alpha-\mathrm{Al}$ solid solution disappeared, replaced by the $\mathrm{Al}-\mathrm{Cu}$ eutectic structure, the $\mathrm{Al}-\mathrm{Cu}-\mathrm{Si}$ ternary eutectic structure, and the $\mathrm{CuAl}_{2}$ intermetallic compound. The $\mathrm{CuAl}_{2}$ intermetallic compound increased along with the increasing of the copper content, which caused the alloy to become brittle and thus downgraded its corrosion resistance. For this reason, the concentration of copper in the developed filler metal should be fixed at about 20 pct.

In order to further depress the melting point of the filler
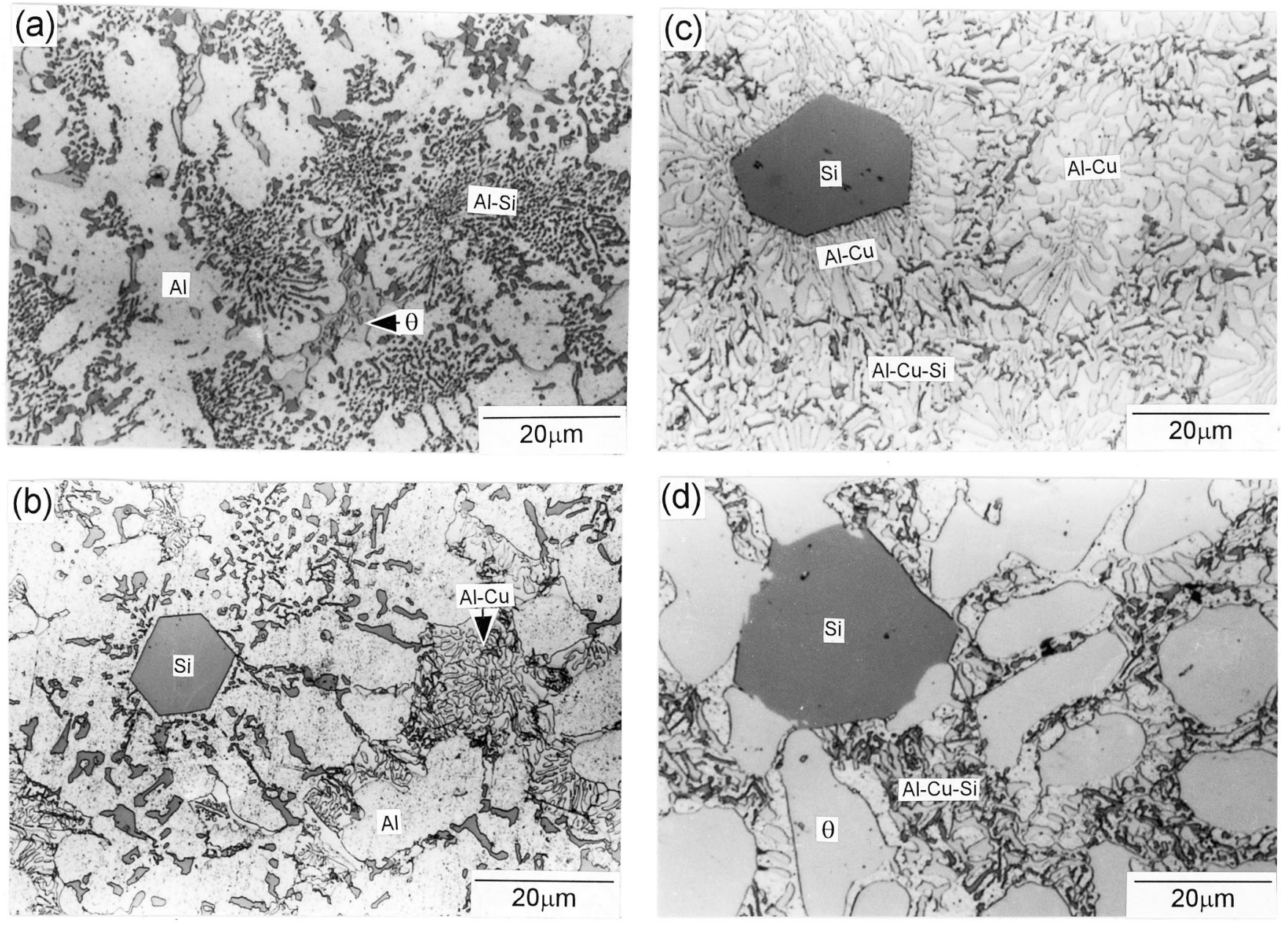

Fig. 4-Microstuctures of Al-Si-Cu filler metals, in casting condition: (a) Al-11.4Si-5Cu, (b) Al-10.8Si-10Cu, (c) Al-9.0Si-25Cu, and (d) Al-7.8Si-35Cu. 


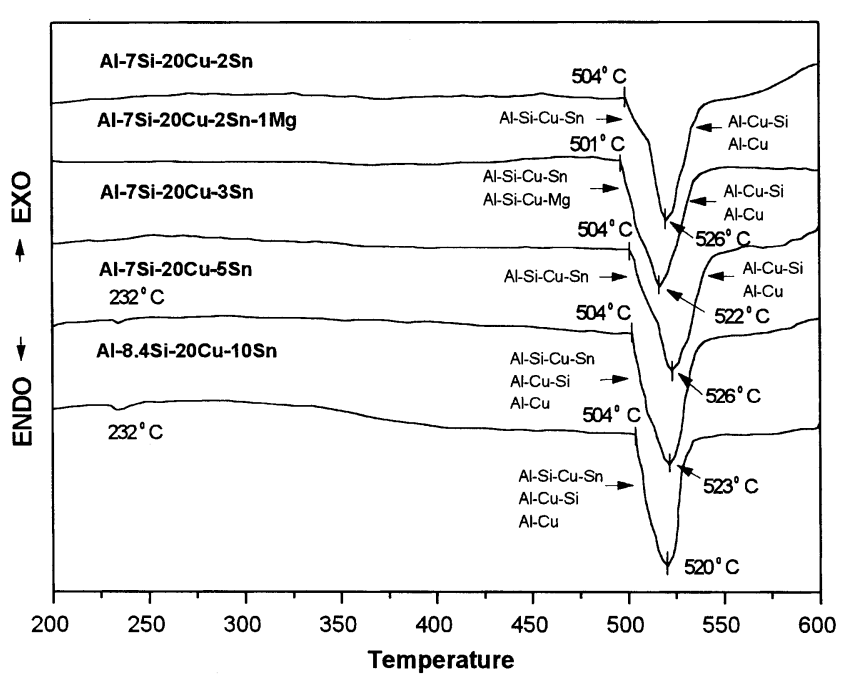

Fig. 5-DTA curves of Al-Si-Cu-Sn-(Mg) filler metals.
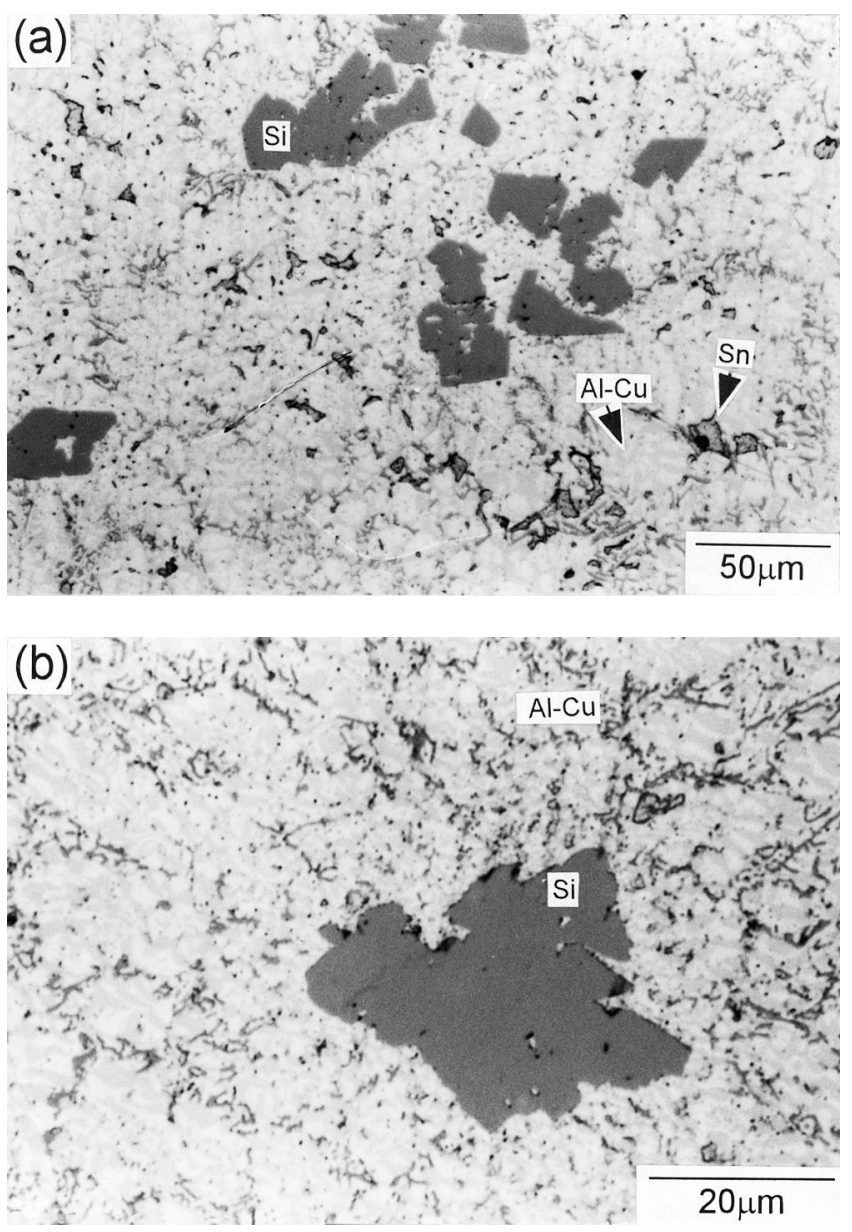

Fig. 6-Microstructures of $\mathrm{Al}-\mathrm{Si}-\mathrm{Cu}-\mathrm{Sn}$ filler metals, in casting condition: (a) $\mathrm{Al}-9 \mathrm{Si}-20 \mathrm{Cu}-5 \mathrm{Sn}$ and (b) $\mathrm{Al}-8.4 \mathrm{Si}-20 \mathrm{Cu}-10 \mathrm{Sn}$.

metal, various quantities of tin were added into the Al-Si$20 \mathrm{Cu}$ alloy. Figure 5 showed the DTA curves of these Al$\mathrm{Si}-\mathrm{Cu}-\mathrm{Sn}$ quaternary alloys. An endothermic peak appeared at $232{ }^{\circ} \mathrm{C}$ in the DTA curves of $\mathrm{Al}-\mathrm{Si}-\mathrm{Cu}-\mathrm{Sn}$ alloys with the tin content higher than 3 pct, which corresponded to the melting point of tin. It implied that the pure tin phase

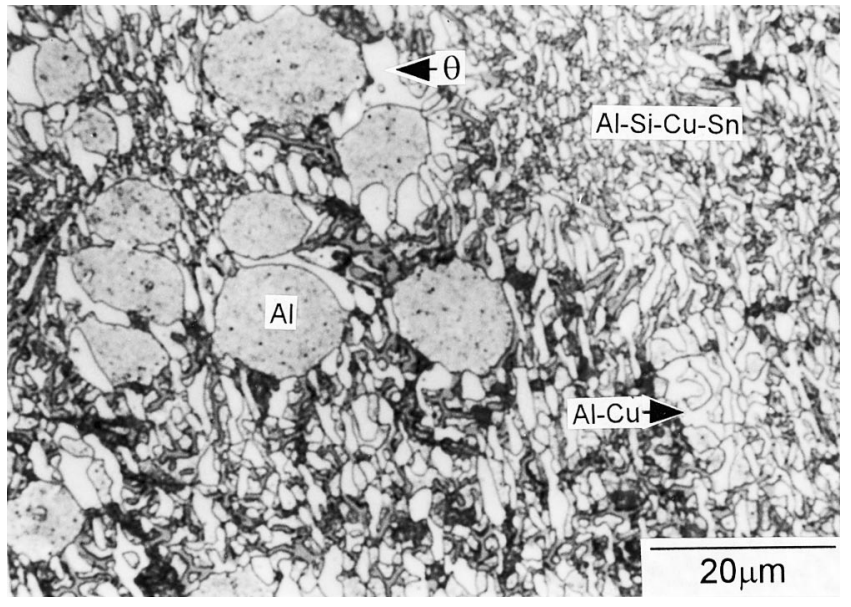

Fig. 7-Microstructure of the Al-7Si-20Cu-2Sn filler metals, in casting condition.

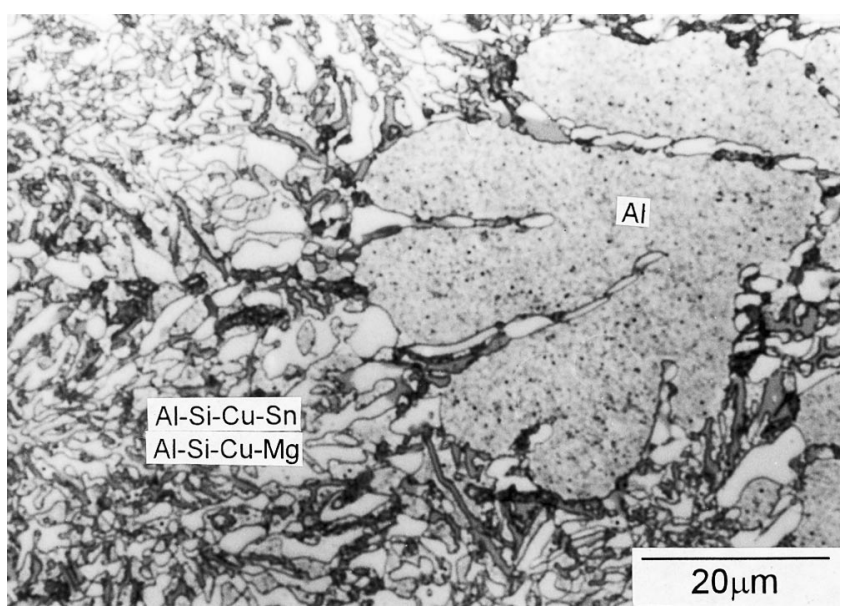

Fig. 8-Microstructure of the Al-7Si-20Cu-2Sn-1Mg filler metal, in casting condition.

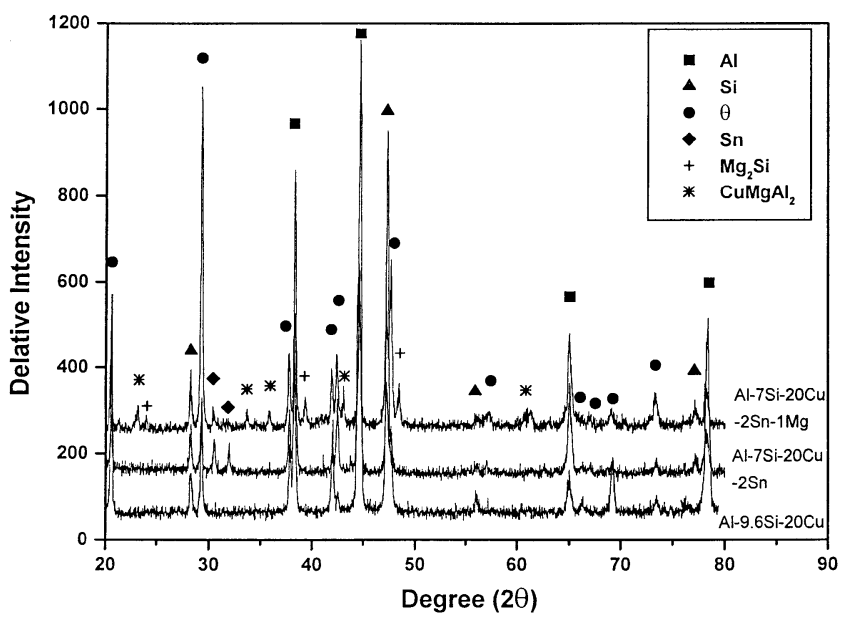

Fig. 9-XRD peaks for the Al-Si-Cu-(Sn,Mg) filler metals in this study.

was retained in these alloys. Another endothermic peak appeared at about $504{ }^{\circ} \mathrm{C}$, which could be attributed to the $\mathrm{Al}-$ $\mathrm{Cu}(-\mathrm{Si}-\mathrm{Sn})$ eutectic reaction. Microstructural observations in Figures 6(a) and (b) confirmed these results, displaying the 

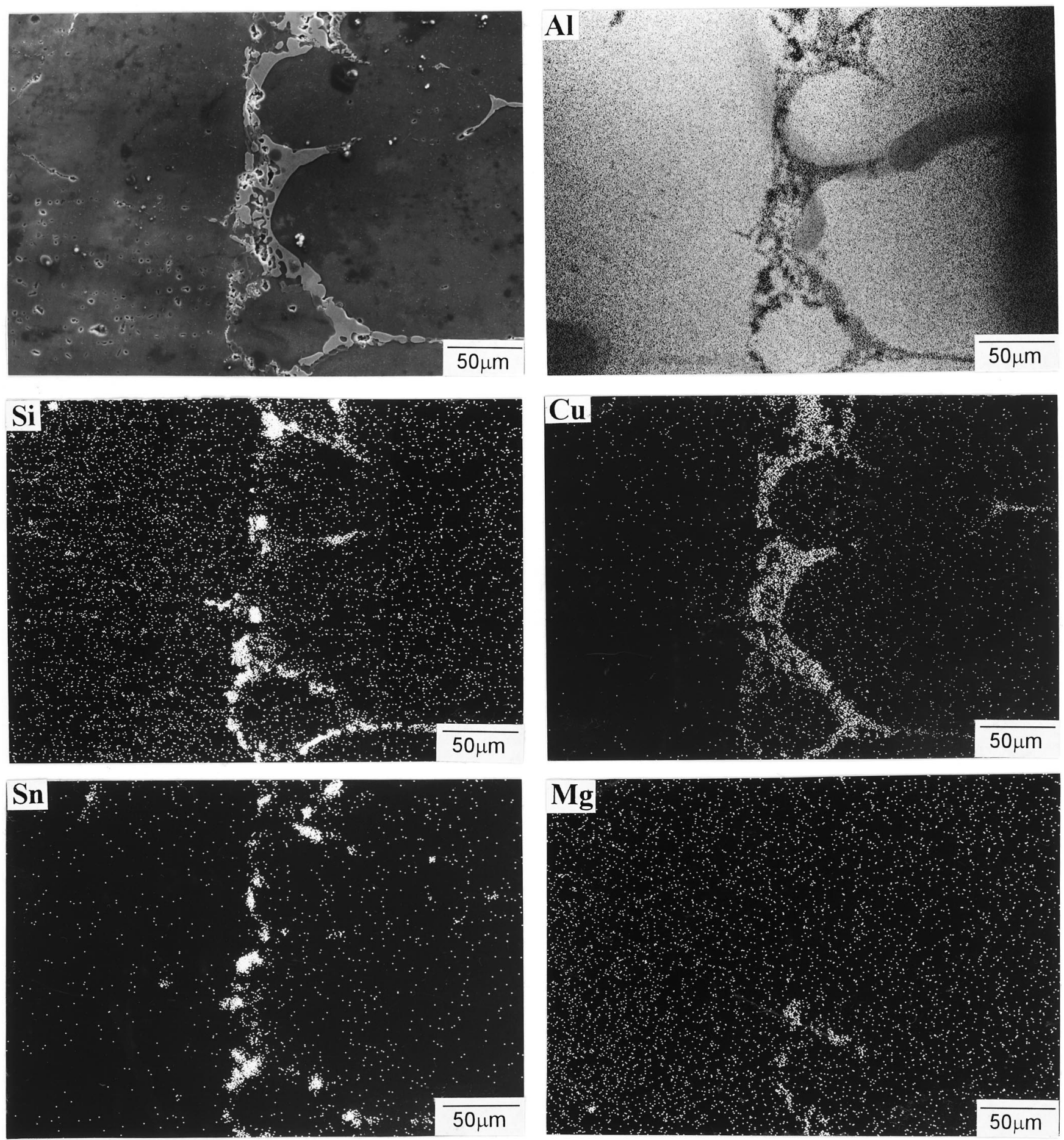

Fig. 10-EPMA element mapping of the 6061-T6 butt joint brazed with Al-7Si-20Cu-2Sn-1Mg filler metal at $550{ }^{\circ} \mathrm{C}$ for $30 \mathrm{~min}$.

matrix of a pure tin phase, a $\mathrm{CuAl}_{2}$ phase, silicon particles, and eutectic Al-Cu, Al-Si-Cu, and Al-Si-Cu-Sn phases. The solidus and liquidus temperatures obtained from the DTA curves in Figure 5 are also presented in Table I. As clearly shown, the solidus temperature drastically decreased by about $20^{\circ} \mathrm{C}$ with the addition of 2 pct tin. However, a further increase of the tin content at above 2 pct did not depress the melting point any further. Instead, the pure tin phase and silicon particles appearing in these high-tin-content alloys appeared to weaken the brazeability. ${ }^{[9]}$ The optimized amount of tin addition should be about 2 pct and a filler metal with the composition of $\mathrm{Al}-7 \mathrm{Si}-20 \mathrm{Cu}-2 \mathrm{Sn}$ was therefore proposed. Figure 7 showed the microstructure of this alloy, which contained none of the pure tin phase and silicon particles. Consistent with the microstructural observation, the endothermic peak at $232{ }^{\circ} \mathrm{C}$ disappeared in the DTA curve of this alloy.

For further improvement of the brazability of this filler metal, 1 pct magnesium was added into the Al-7Si-20Cu$2 \mathrm{Sn}$ alloy. In this case, magnesium acted as a wetting agent 
Table II. Bonding Strengths of the 6061-T6 Butt Joints Brazed with Al-12Si and Al-7Si-20Cu-2Sn-1Mg Filler Metals

\begin{tabular}{|c|c|c|c|c|}
\hline Filler Metals & $\begin{array}{l}\text { Bonding } \\
\text { Conditions }\end{array}$ & $\begin{array}{l}\text { Heat Treatment } \\
\text { after Brazing* }\end{array}$ & $\begin{array}{c}\text { Bonding Strength } \\
(\mathrm{MPa})\end{array}$ & $\begin{array}{l}\text { Fracture } \\
\text { Location }\end{array}$ \\
\hline $\mathrm{Al}-12 \mathrm{Si}$ & $600{ }^{\circ} \mathrm{C}, 30 \mathrm{~min}$ & - & $59 \pm 18$ & butt joint \\
\hline $\mathrm{Al}-12 \mathrm{Si}$ & $600{ }^{\circ} \mathrm{C}, 60 \mathrm{~min}$ & T6 & $67 \pm 7$ & butt joint \\
\hline Al-7Si-20Cu-2Sn-1Mg & $550{ }^{\circ} \mathrm{C}, 30 \mathrm{~min}$ & - & $74 \pm 10$ & butt joint \\
\hline Al-7Si-20Cu-2Sn-1Mg & $575^{\circ} \mathrm{C}, 30 \mathrm{~min}$ & - & \pm 7 & butt joint \\
\hline $\mathrm{Al}-7 \mathrm{Si}-20 \mathrm{Cu}-2 \mathrm{Sn}-1 \mathrm{Mg}$ & $600{ }^{\circ} \mathrm{C}, 30 \mathrm{~min}$ & - & $95 \pm 9$ & butt joint \\
\hline $\mathrm{Al}-7 \mathrm{Si}-20 \mathrm{Cu}-2 \mathrm{Sn}-1 \mathrm{Mg}$ & $550{ }^{\circ} \mathrm{C}, 60 \mathrm{~min}$ & T6 & $147 \pm 12$ & butt joint \\
\hline $\mathrm{Al}-7 \mathrm{Si}-20 \mathrm{Cu}-2 \mathrm{Sn}-1 \mathrm{Mg}$ & $600^{\circ} \mathrm{C}, 60 \mathrm{~min}$ & - & $109 \pm 15$ & butt joint \\
\hline Al-7Si-20Cu-2Sn-1Mg & $600{ }^{\circ} \mathrm{C}, 60 \mathrm{~min}$ & T6 & $196 \pm 19$ & butt joint \\
\hline
\end{tabular}

*T6 temper condition: solution treated at $520^{\circ} \mathrm{C}$ for $1.5 \mathrm{~h}$, water quenched, and then aged at $175{ }^{\circ} \mathrm{C}$ for $8 \mathrm{~h}$.

$* *$ The ultimate tensile strength of the 6061-T6 Al alloy for brazing tests was $331 \mathrm{MPa}$.

by removing the residual oxygen and moisture on the brazed aluminum surface and thus reducing the oxide film. The final composition of the developed filler metal was $\mathrm{Al}-7 \mathrm{Si}$ $20 \mathrm{Cu}-2 \mathrm{Sn}-1 \mathrm{Mg}$, which possessed a melting range of $501{ }^{\circ} \mathrm{C}$ to $522{ }^{\circ} \mathrm{C}$ (shown in Figure 5). The microstructure of this alloy as shown in Figure 8 contained an $\alpha$-Al solid solution, fine silicon particles, a pure tin phase, and $\mathrm{CuAl}_{2}, \mathrm{CuMgAl}_{2}$, and $\mathrm{Mg}_{2} \mathrm{Si}$ intermetallic compounds. The XRD peaks as shown in Figure 9 confirmed the phases as observed in the microstructure of this Al-7Si-20Cu-2Sn-1Mg filler metal. In Figure 9, XRD analyses for Al-9.6Si-20Cu and Al-7Si20Cu-2Sn filler metals were also included, which were also consistent with the DTA results and microstructural observations for both alloys.

Figure 10 showed the microstructure of the joint where a 6061-T6 aluminum alloy was brazed with Al-7Si-20Cu$2 \mathrm{Sn}-1 \mathrm{Mg}$ at $550{ }^{\circ} \mathrm{C}$ for 30 minutes. The butt joint region extended to a width of about $400 \mu \mathrm{m}$, where the filler metal penetrated intergranularly into the 6061-T6 butt joint. The EPMA mapping in Figure 10 revealed that the aluminum content in the butt joint decreased ostensibly after brazing. The depletion of aluminum was replaced by the enrichment of copper elements. The $\mathrm{Si}$ and $\mathrm{Sn}$ elements appeared as clusters of intermetallic compounds containing $\mathrm{Al}$ and $\mathrm{Mg}$. When compared with the XRD analysis in Figure 9, this implied that the composition of this Al-7Si-20Cu-2Sn-1Mg filler metal had greatly changed during the brazing reaction with the 6061-T6 alloy. Table II showed the bonding strengths of the 6061-T6 alloy brazed with Al-12Si and Al7Si-20Cu-2Sn-1Mg filler metals at various temperatures. Since the 6061-T6 aluminum alloy possessed a high ultimate strength of $331 \mathrm{MPa}$, the brazed specimens in all cases fractured along the butt joint after tensile tests as indicated in Table II. Furthermore, as Table II evidently showed, when the 6061-T6 alloy was brazed with the conventional Al-12Si filler metal at $600{ }^{\circ} \mathrm{C}$ for 60 minutes, and the brazements were henceforth subjected to a T6 treatment, the bonding strength could reach only to about $67 \mathrm{MPa}$. However, the bonding strength could go up to $147 \mathrm{MPa}$ for the same 6061T6 alloy when brazed with the Al-7Si-20Cu-2Sn-1Mg filler metal even at a lower temperature of $550{ }^{\circ} \mathrm{C}$ for 60 minutes and then subjected to a T6 treatment. When the bonding temperature was increased to $600{ }^{\circ} \mathrm{C}$ under the same bonding conditions, the bonding strength of the Al-7Si-20Cu-2Sn$1 \mathrm{Mg} / 6061-\mathrm{T} 6$ brazement went up dramatically to $196 \mathrm{MPa}$. Figure 11 showed that in this optimized case the fractography
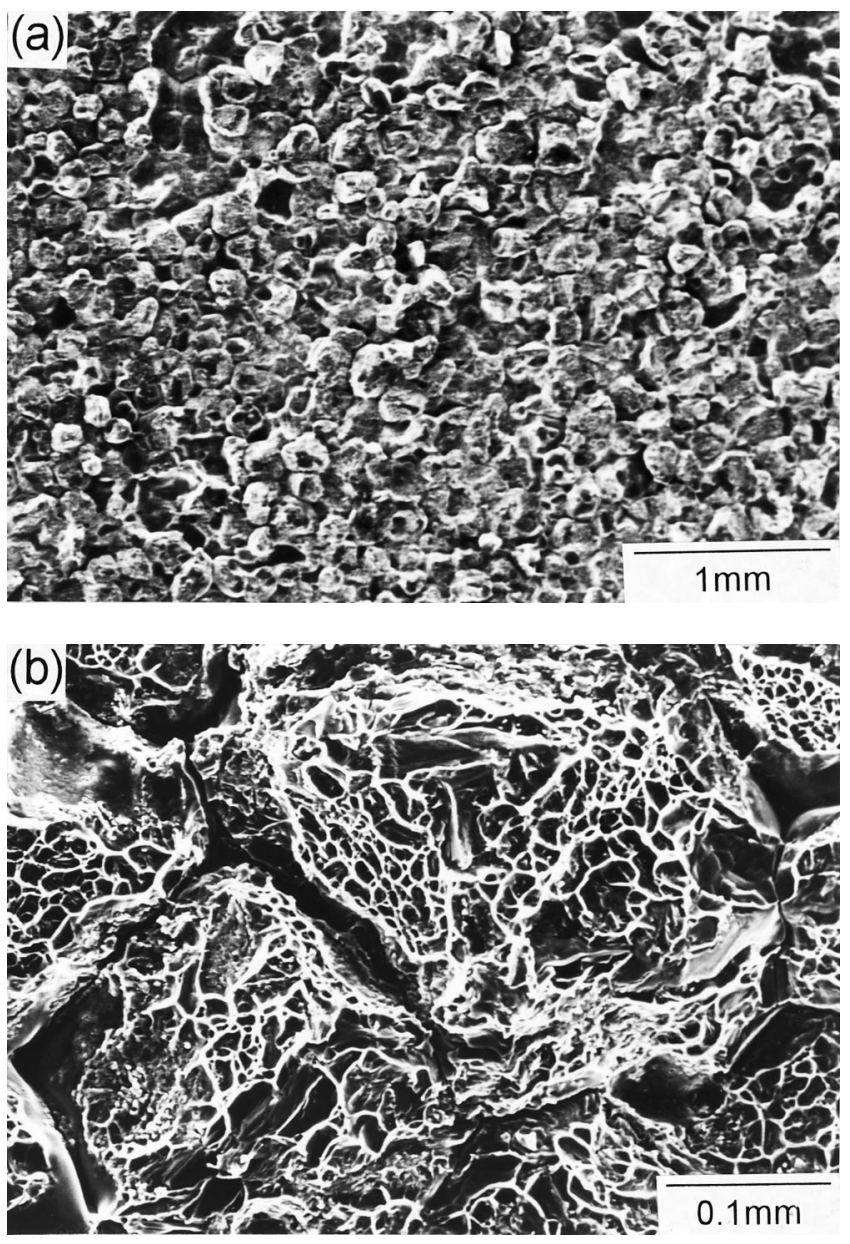

Fig. 11- $(a)$ and $(b)$ Fractographs of the tensile tested 6061-T6 butt joint brazed with $\mathrm{Al}-7 \mathrm{Si}-20 \mathrm{Cu}-2 \mathrm{Sn}-1 \mathrm{Mg}$ filler metal at $600{ }^{\circ} \mathrm{C}$ for $60 \mathrm{~min}$ followed with a T6 post-treatment.

of brazement after tensile tests revealed dimple characteristics, which implied that the brazement possessed a ductile fracture mode. The sound joining result was attributed to the much lower liquidus of the Al-7Si-20Cu-2Sn-1Mg filler metal than the brazing temperature and the addition of magnesium to the filler metal that had enabled the molten filler metal to break through the aluminum oxide layer on the bonded surface. Such a bonding condition would be ideal for this filler metal $\mathrm{Al}-7 \mathrm{Si}-20 \mathrm{Cu}-2 \mathrm{Sn}-1 \mathrm{Mg}$ to exercise its 
good wettability and flowability in the clearance of aluminum assemblies.

\section{CONCLUSIONS}

1. The solidus temperatures of the Al-Si-Cu ternary alloys in this study decreased with increasing amount of copper administered. However, their liquidus temperatures fell from $593{ }^{\circ} \mathrm{C}$ to $534{ }^{\circ} \mathrm{C}$ with the addition of copper from 0 to $30 \mathrm{pct}$ and then climbed up with further increasing of the copper content.

2. The microstructure of Al-Si-Cu alloys consisted of the Al-Si eutectic structure, the $\alpha$-Al dendrite solid solution, and the $\mathrm{CuAl}_{2}(\theta)$ phase. For $\mathrm{Al}-\mathrm{Si}-\mathrm{Cu}-\mathrm{Sn}$ quaternary alloys, the microstructure contained a pure tin phase, a $\mathrm{CuAl}_{2}$ phase, silicon particles, and eutectic $\mathrm{Al}-\mathrm{Cu}, \mathrm{Al}-$ $\mathrm{Si}-\mathrm{Cu}$, and $\mathrm{Al}-\mathrm{Si}-\mathrm{Cu}-\mathrm{Sn}$ phases.

3. The melting temperatures of the Al-Si-Cu alloys decreased further by about $20{ }^{\circ} \mathrm{C}$ with the addition of 2 pct tin.

4. When the newly developed $\mathrm{Al}-7 \mathrm{Si}-20 \mathrm{Cu}-2 \mathrm{Sn}-1 \mathrm{Mg}$ filler metal was employed to braze a $6061-\mathrm{T} 6$ alloy at $600{ }^{\circ} \mathrm{C}$ for 60 minutes, and then subjected to a T6 treatment, the bonding strength was $196 \pm 19 \mathrm{MPa}$. However, the bonding strength was only $67 \pm 7 \mathrm{MPa}$ for the 6061-T6 alloy when brazed with the conventional Al-12Si filler metal under the same bonding conditions.

\section{REFERENCES}

1. Y. Sugiyama: Weld. Int., 1989, No. 8, pp. 700-10.

2. H. Kawase, T. Takemoto, M. Asano, I. Kawakatsu, and K. Liu: Weld. J., 1989, vol. 68, pp. 396s-403s.

3. T. Hattori, S. Sakai, A, Sakamoto, and C. Fujiwara: Weld. J., 1994, vol. 73, pp. 233s-240s.

4. G. Humpston, S.P.S. Sangha, and D.M. Jacobson: Mater. Sci. Technol., 1995, vol. 11, pp. 1161-67.

5. D.M. Jacobson, G. Humpston, and S.P.S. Sangha: Weld. J., 1996, vol. 75, pp. 243s-250s

6. K. Suzuki, M. Kagayama, and Y. Takeuchi: J. Jpn. Inst. Light Met., 1993, vol. 43 (10), pp. 533-38.

7. T. Kayamoto, J.H. Kim, S. Saito, and T. Onzawa: Proc. Workshop. J. Weld. Soc., 1994, vol. 12, pp. 495-501.

8. L.F. Mondolfo: Aluminum Alloys-Structure and Properties, Butterworth and Co., London, 1976, pp. 513-15.

9. T. Osawa: Weld. J., 1995, vol. 74, pp. 206s-212s 